\title{
Exploring the status of Guidance and Counselling services in Selected Public Secondary Schools in Chilanga District, Zambia
}

\author{
Christopher Kabamba ${ }^{1}$, Kasonde Mundende ${ }^{2}$, Francis Simui ${ }^{3 *}$ \\ ${ }^{1}$ Shalom School, University of Zambia \\ ${ }^{2,3}$ Institute of Distance Education, University of Zambia
}

\author{
*Corresponding Author: Francis Simui, PhD, Institute of Distance Education, University of Zambia
}

\begin{abstract}
The study explored the status of Guidance and Counselling services in five public secondary schools in Chilanga district. Participants consistent of five head teachers, 10 guidance teachers, 10 pupils and two District Education Board secretary officers purposively drawn from a cluster of five secondary schools. The findings revealed Guidance and Counselling services available in schools are clustered within educational, vocational, personal, social and or therapeutic. It also revealed that the teachers and pupils were aware of Guidance and Counselling services, although much was needed for Guidance and Counselling services to be effectively implemented, so that it serves its intended purpose. The major challenges encountered in the implementation of Guidance and Counselling services included lack of funding, lack of offices for counselling, limited number of qualified guidance teachers and guidance teachers being subject teachers. Thus, it was recommended that the Ministry of General Education should come up with Guidance and Counselling policy that will guide the practice of Guidance and Counselling in schools, create positions of full time counselors in secondary school, and devise a deliberate training programme to ensure that all school counselors receive adequate training. Further, the Ministry need to invest in the guidance reference materials.
\end{abstract}

Key words: Guidance \&Counselling, Management, Secondary Schools, Chilanga, Zambia

\section{INTRODUCTION}

This paper is an excerpt from the principal researcher's Master Education Management dissertation. The Masters programme was offered by the University of Zambia (UNZA) in collaboration with the Zimbabwe Open University and had been running since 2014 (Manchishi, Simui, Ndhlovu \& Thompson, 2020; Simui, 2018; Simui, Kasonde-Ngandu, Cheyeka \& Kakana, 2018).

UNESCO (2013) reveals that many countries in the world have identified and recognized the importance of Guidance and Counselling in the provision of education and training due to its international recognition of improving all aspects of education to enhance quality education. In Zambia, the need for Guidance and Counselling in the education provision is recognized in the education Act No. 23 of 2011 as well as the 1996 Educating Our Future policy document on education. Furthermore, the ministry places emphasis on strengthening school Guidance and Counselling services through the provision of guidelines on how to effectively implement Guidance and Counselling services in schools, (MOGE, 2015).

\subsection{Statement of the Problem}

Despite the presence of a legal framework on guidance and Counselling services in Zambia, research reports indicate persistent challenges in the provision of services. However, it is not clear what the status of service provision is in Chilanga district. Thus, this study explored the status of service provision of Guidance and Counselling programmes in selected secondary schools in Chilanga district.

\subsection{Purpose of the Study}

The purpose of the study was to explore status of service provision of Guidance and Counselling in public selected secondary schools in Chilanga District. 
Exploring the status of Guidance and Counselling services in Selected Public Secondary Schools in Chilanga District, Zambia

\subsection{Study Objectives}

The study was guided by the following specific objectives:

- Explore the barriers in the implementation of Guidance and Counselling activities in selected public secondary schools in Chilanga District.

- Describe how teachers support the Guidance and Counselling services in schools.

- Explore the challenges that pupils face in accessing services in schools.

\subsection{Theoretical Framework}

This study was guided by ecological system model by Bronfenbrenner (1989), who states that a child passes through several layers, which play an important role in the area of Guidance and Counselling. According to Bronfenbrenner, the inner most layer is known as Microsystems is the layer closest to the child and comprises the structures which the child has a direct contact. Micro system encompasses the relationships and interactions a child has with his or her direct surroundings such as family, school, neighborhoods, or childcare environments. This layer is followed by Mesosystem layer which connects two or more systems in which children, parent and family live. Additionally, the exo-system defines the larger social system in which a child does not directly function (Karega, 2008). Finally, the Macro-system layer is composed of cultural values, customs and laws. In line with the current study each of the various systems are said to play a part in the delivery of Guidance and Counselling services, but to what extent was the critical subject of discussion.

\section{REVIEW OF RELATEd LiteratURE}

According to Nkhata (2010), Guidance and Counselling as used today evolved in the United States of America in the 1900s, although the rigorous thinking in this direction had started earlier. It prompted from the awareness of social problems plaguing America and practical attempts to solve them. Guidance and Counselling thus emerged and developed as an American product. The educational Guidance and the school Counselling unit is a special unit established in schools to solve study related and non-related problems of students. Guidance and Counselling play an important role in schools for the child's future success. This means that Guidance and Counselling are an important tool in shaping the orientation in a child from negative ideas that is planted in the child by his or her peers. Egbo (2013:54) observes that the total development of a child can only be achieved better in an environment which is conducive for teaching and learning.

Makumba (2013), asserts that counselling is a psychological process by which a professional person helps to relate normal client explore, understand and accept behaviour so that future behavioural choices can be made, particularly those of educational or vocational nature. According to Mwamba (2011), Guidance and Counselling is a relationship between two individuals; the counsellor and the client. Guidance and Counselling are a continuing process for the developmental needs of learners. Guidance is considered a life-long process that involves helping individuals both as part of a group and at the personal life.

Guidance as a concept involves the utilization of a part of view to help an individual accept and use his or her abilities, aptitudes and interests and attitudinal patterns in relation to his or her aspirations. As an educational construct, it involves the provision of experience which assists individuals to understand themselves, (MOGE, 2015). That simply means that counselling aims at helping the clients to come to terms with the problem and assist the client with skills to solve their current and future problems. It is concerned with bringing about desirable personality changes, voluntarily and consciously in the client (MOGE, 2015:3).

The need for formal Guidance and Counselling in Zambia is recognized now than ever before. Guidance and Counselling is important in many areas such as helping the youth understand themselves and to know their abilities and skills. In addition, Guidance and Counselling is the total development of the student. As Ministry of Education (2009) reveals that to educate a person in mind and not in morals is to educate a menace in the society.

Therefore, Guidance and Counselling helps students to harmonize their abilities, interests and values thereby enabling them to develop their potential fully. As self-knowledge, it helps one to formulate 
Exploring the status of Guidance and Counselling services in Selected Public Secondary Schools in Chilanga District, Zambia

realistic life goals and plans. In addition, total development of a student is vital because individual differences are then expected, accepted, understood and planned for. This is the reason why after the SADC ministers of education meeting held in September 2005 in Mbabane, Swaziland and August, 2008 in Lusaka, Zambia also emphasized the need for Guidance and Counselling by calling for its strengthening through the schools as centres of care and support programmes. The symposium which was held at the Mulungushi International conference centre in 2008 in Lusaka and the meeting to review Educating Our Future Policy Document in September, 2009 acknowledged the importance of Guidance and Counselling, (MOGE, 2015).

Furthermore, Weissberg \& Myrisks (2007), also carried out a study on the helpfulness of useful Guidance and Counselling programme in Missouri, United States of America. The study noted that school counsellors who were more fully involved in providing learners with a unique network of emotional and instructional support services were more likely to exert an optimistic impact than counsellors who did not implement such activities. Such that this study differs from the above in that the above studies had focused on how teachers can integrate Guidance and Counselling in the learning process whereas this study was to explore on the implementation and management of Guidance and Counselling in the selected secondary schools in Chilanga district.

Since the time Guidance and Counselling was established in secondary schools, teachers are trying to provide the services to the learners. As a rapid implementation and management conducted in Uganda by the Ministry of Education in June 2004 found that most schools were doing all they could in order to provide Guidance and Counselling to the learners in schools (Ministry of Education and Sports, 2005). The Ministry of Education and Sports (2005) in Uganda reported that Guidance and Counselling was a component within their school curriculum meaning that every teacher trainee gets exposed to Guidance and Counselling skills and knowledge during his or her training. This has helped Uganda to successful implementation and management of Guidance and Counselling in its schools even though there are a lot of challenges. The report further stated that schools in Uganda used different modes and approaches in delivering Guidance and Counselling to their pupils, (Makumba, 2013).

In Tanzania, Guidance and Counselling is as well provided even though it is not on the school time table. Makumba (2013) reports that as regards to the origin and development of Guidance and Counselling in Tanzanian at primary levels, there are no defined teachers to counsel pupils in schools, there is no programme or time tabled action on counselling. The counselling is left to voluntary teachers and other stakeholders interested in education. Makumba also pointed out in his research that although literature on Africa in Guidance and Counselling is scanty, there is evidence that Guidance and Counselling is provided to the schools in most countries in Africa. In some countries such as Malawi, Zambia, Tanzania and Swaziland, Guidance and Counselling did not exist until the late sixties, (Weinten, 2007). In African countries Guidance and Counselling movement is relatively new in the education system.

However, in Zambia, Guidance and Counselling services has not even been mentioned in the syllabus for grades 1-7 in the primary schools but is treated as a cross cutting issues. In a related study by Chipili, Ndhlovu and Simui (2018) on access to career Guidance through Information and Communication Technology by learners with Visual Impairment in selected Secondary schools of Zambia, learners with visual impairments had limited access to career and vocational related information through ICTs in Zambian schools.

UNESCO (2006) noted that Guidance and Counselling was not considered as a subject and was not time tabled but was only a comprehensive programme. This has led to a huge challenge for teachers in Zambia to provide Guidance and Counselling to the learners especially in primary schools. From the literature reviewed on Africa, it is evident that Guidance and Counselling is provided in African schools though its efficacy is still unknown (Loescher, 2007). Macharia (2007) notes that problems that affect the development of putting up effective Guidance and Counselling programme in eastern and southern African countries include, the imposition of western models of counselling which does not reflect the African culture including illiteracy and ignorance.

This this section has highlighted key studies on Guidance and Counselling across the globe, it is clear that the provision of Guidance and Counselling services in secondary schools was inadequately in 
Exploring the status of Guidance and Counselling services in Selected Public Secondary Schools in Chilanga District, Zambia

most countries. However, the question that can come in is that of: do Guidance and Counselling services serve its intended purpose in schools? Therefore, this study endeavoured to fill this gap.

\section{Methodology}

\subsection{Research Design}

The qualitative Methodology weaved within a Case study design was applied to generate evidence on status of Guidance and counsellingservices in selected public secondary schools in Chilanga district. A total of 27participantswere purposively engaged comprising of:

- 2 District Education Board secretary officers were interviewed, because they help in monitoring of Guidance and Counselling in schools,

- 10 Teachers from the secondary schools, chosen because they were the ones who actually implement the services of Guidance and Counselling.

- 5 head teachers from the selected secondary schools were interviewed.

- 10pupils from the selected schools, who happened to be the primary beneficiaries,

Purposive sampling was applied in line with (Creswell, 2012). The idea behind the purposefully selecting of informants was to answer the research questions from 'information rich' persons (Karega, 2008).

\subsection{Trustworthiness\& Ethical Considerations}

The researchers sought ethical clearance from the University of Zambia. Moreover, all the information that were collected was strictly treated as confidential and were not used for any purposes other than the intended one. Additionally, consent was sought from the respondents and the researcher ensured that the subject participants who voluntarily participated in this study and maintain an open and honest approach to the study. The consent form was given and signed by the respondents. The names of the participants was protected and kept confidential and if the participant wished to withdraw, they were free to do so.

\section{Presentation of Findings}

The findings of this study are presented in line with the research questions

- What Guidance and Counselling services exist in secondary schools in Chilanga District?

- What barriers exist in the implementation of Guidance and Counselling activities in secondary schools in Chilanga District?

- How teachers support Guidance and Counselling services in schools?

- What challenges do pupils face in accessing Guidance and Counselling services in schools?

\subsection{Types of Guidance and Counselling Services Offered}

On the question of the types of Guidance and Counselling services offered to learners in schools, one teacher observed that,

Educational; Health or Therapeutically; Personal and Vocational Guidance and Counselling.

The head teachers and teachers were also asked on the cases frequently attended to in Guidance and Counselling (T4, 2019).

The study revealed that all 5 head teachers, 2 officers from DEBs, 25 pupils and 10 teachers were aware of Guidance and Counselling services that were offered in schools.

With regards to whether the schools provided Guidance and Counselling services to pupils,

One teacher from Farron secondary school stated that:

As teachers we do provide Guidance and Counselling to our pupils in this school by giving advice to them and helping them sort out their problems even though some fail to take the teacher's advice. As teachers we are supposed to help our pupils in their career path and in their decision making (T2, 2019). 
Exploring the status of Guidance and Counselling services in Selected Public Secondary Schools in Chilanga District, Zambia

One guidance teacher at the same school also said that,

At this school we have a department of Guidance and Counselling which looks into the affairs of pupils' problems and tries to help them solve some of their problems. There are teachers who belong to the department of counselling and are involved in helping pupils in their problems (T1, 2019).

Ata different school, Aadimo secondary school the head teacher lamented that:

We provide counselling services to the pupils in this school even though we have only two untrained guidance teachers against 1020 pupils in school (T7, 2019).

Another teacher from Modimo said that:

In this school Guidance and Counselling is provided to pupils by all the teachers at any time but within the school time. Pupils bring different problems to us as teachers and we help them. At times cases involve parents and we summon them to come to school although some of the parents are not co-operative and do not come to school when summoned by the teachers." (T9, 2019).

However, in another school, Narumo secondary school, pupils responded that:

They received guidance, for example, 12 pupils said that they often benefited from Guidance and Counselling service and the 9 pupils rarely benefited from the counselling services and 6 pupils never received Guidance and Counselling service from their school (P4, 2019).

\subsection{Barriers to the Provision of Guidance and Counselling Services in Schools}

On the barriers faced in the implementation of Guidance and Counselling services in schools, one guidance teacher Adimo secondary school lamented that:

It is a big challenge to implement Guidance and Counselling to the pupils at this school because there is no enough time allocated to the guidance teachers in which we can attend to some pupils. Hence, we have to find our own time to do the counselling to the pupils. Which is quite challenging.(T6, 2019).

Another teacher from a different school, Didimo secondary stated that:

Providing Guidance and Counselling to pupils is not easy in this school, some pupils fail to open up especially on issues of pregnancies. The guidance teacher is forced to probe further for the pupil to open up and then finds out more before counselling the pupil (T10, 2019).

The other teacher from Narumo secondary school also said that:

There are limited materials and the administration provides minimum support. We use our own materials to facilitate counselling in this school. They are no books to use by the teachers. At times we have to use our own initiative to come up with a programme (T7, 2019).

The other teacher from Narumo also observed that,

The major challenge faced is that, some guidance teachers do not keep pupil's information that go for counselling confidential. This makes pupils not to report cases to guidance teachers for fear of being publicized in school(T8, 2019).

Another head teacher from a different school, Didimo secondary school said that:

Having unqualified guidance teachers in this school is a big challenge. Untrained guidance teachers have no idea about counselling, so they end up shouting at pupils each time they come to them for help $(H T, 2019)$.

Teachers were also asked if the administration had supported Guidance and Counselling services in schools. Among 10 teachers that participated in the study 8 indicated that they had received support from the administration. Among the teachers who said that they rarely received support from the school administration, one participant from Farron secondary school indicated that, 
There is no educational policy which mandates head teachers to allocate sufficient time and resources to ensure that all learners receive the necessary Guidance and Counselling services in schools. This has made it difficult to provide Guidance and Counselling services to effectively implement to the learners (T9, 2019).

\subsection{Challenges Faced by Pupils in Benefiting from Guidance and Counselling}

One pupil from Narumo secondary school had this to say:

We have limited periods for school Guidance and Counselling meetings and that hinders us to acquire the Guidance and Counselling services( $\mathrm{P} 1,2019)$.

Another pupil from another school, Aadimo secondary reported that:

Guidance and Counselling teachers are not consistent in meeting their schedules with us. Moreover, another pupil from the same school added that Guidance and Counselling teachers they have an overload thus the reason why they do not meet us consistently $(P 6,2019)$.

A pupil from Didimo secondary school reported that:

Some teachers lacked information concerning vocational careers when they were asked by pupils hence causing pupils not to trust them, (P8, 2019).

In a focused group discussion, one pupil from Farron secondary school lamented that:

Sometimes Guidance and Counselling teachers do not help pupils to find a realistic solution to the problem that they face $(P 2,2019)$.

One pupil from Narumo secondary school retorted that, we fear to report the problems that we encounter because some counsellors expose us to our fellow pupils when we seek help $(P 2,2019)$.

Three pupils unanimously observed that,

At this school, we do not have the timetable for the programme of Guidance and Counselling hence, we do not benefit from Guidance and Counselling services. (P2,P4 \& P9, 2019).

However, in a Focused Group Discussion, one pupil from Farron secondary school said that,

As pupils we feel shy to seek help because offices are usually full with other teachers since there no specific offices for Guidance and Counselling at this school. This idea was supported by other pupils in the discussion (P4, 2019).

In a focused Group Discussion, one pupil from Aadimo secondary school observed that,

Due to the limited number of Guidance and Counselling teachers, we fail to meet them since they are always busy with teaching and other school programmes. Hence, that hinders us to benefit from the Guidance and Counselling services at this school (P7, 2019).

One of the officers indicated that:

We do not have enough human resource for monitoring the implementation of Guidance and Counselling in schools since some teachers needs supervision in order for them to implement a certain program into the education system. The government does not fund them to that extent in order for them to go and monitor the implementation of Guidance and Counselling in schools (D2, 2019).

The other officer indicated that:

In most of the Zambian schools, there no trained Guidance and Counselling teachers and that lead them to start doing things through trial and error method. Hence, that becomes a challenge for the implementation of Guidance and Counselling programs. (D1, 2019). 
Exploring the status of Guidance and Counselling services in Selected Public Secondary Schools in Chilanga District, Zambia

\subsection{Mitigating Challenges Faced by Pupils in Accessing Guidance \& Counselling Services}

Furthermore, the following were some of the responses given by pupils from five schools that participated in the study in response to how the challenges faced in benefiting from Guidance and Counselling services can be minimized?

Two pupils from Farron and Narumo secondary schools indicated a similar statement that, They should educate more teachers on how they should be handling pupils with problems and making sure that guidance teachers are friendly (P4 and P5, 2019). The other pupil from Aadimo secondary school also indicated that, Guidance teachers should be should be open and courageous to learners when it comes to handling some issues (P1, 2019).Another pupil from Farron secondary said that, Guidance and Counselling should be examinable in schools just like English, mathematics and other subjects and guidance should be having frequent meetings (P2, 2019).

Another pupil by the name of P6, from Didimo secondary school indicated that, the school should employ more qualified counsellors because we only have one who happened to be the secretary again.In addition, another pupil said that, the school should probably provide more qualified counsellors and they should be more concerned with career talks in order to get views of pupils who have problems $(P 8,2019)$.

\section{DISCUSSION OF THE FINDINGS}

\subsection{Types of Guidance and Counselling Services Offered to Learners}

On the question of the types of Guidance and Counselling services offered to learners in schools, the following were cited: (i) Educational; (ii) Health or Therapeutically; (iii) Personal and (iv) Vocational Guidance and Counselling. The services noted above are similar to the ones identified by Egbo (2013) and Makumba (2013).

\subsection{Awareness of Guidance and Counselling Services in Schools}

The research revealed that in five schools in which the study was carried out, the provision of Guidance and Counselling services was not adequate. However, a few teachers observed that, they provided Guidance and Counselling to pupils in schools by giving advice to them. It should be noted that the provision of Guidance and Counselling in secondary schools helps pupils to reform in their bad behaviour and develop interest in some career. This is supported by Kochhar (2010) who argues that lack of Guidance and Counselling services in schools disadvantages pupils in terms of career interest, self-awareness and character formation among others.

Moreover, pupils appear to be aware of Guidance and Counselling services in schools and most of them had benefited from the services while a few were not aware of Guidance and Counselling. The apparent reason for not being aware of the services was that, the Guidance and Counselling department never sensitized pupils about the services that were on offer through the department of Guidance and Counselling. The above disclosure is of great concern as Guidance and Counselling services are meant to help all the pupils in schools for them to attain their full potential in their academic areas. Apart from that, Guidance and Counselling services help a great deal in molding pupils into informed citizens. As Eyo, Joshua and Esuong (2010) states that, children can be molded to be good citizens when they are well guided and counselled.

\subsection{Challenges Faced in the Provision of Guidance and Counselling Services in Schools}

Referring to the responses given by 5 head teaches and 10 teachers who took part in the study, most of the responses revealed that they had challenges in the provision of Guidance and Counselling services.

Guidance and counselling in schools lacked financial support to facilitate the day-to-day running of the services that guidance department needs. This was because the department needs to be funded accordingly so that it can arrange for instance career trips, inviting different professionals and address issues concerning careers and/or how to keep pupils themselves in good health and many other aspects. It is against this background that, all these programmes can only be carried out if there is a proper financial support. 
Exploring the status of Guidance and Counselling services in Selected Public Secondary Schools in Chilanga District, Zambia

In addition, there has been a non-availability of Guidance and Counselling materials in schools for effective execution of Guidance and Counselling services to the pupils. In fact, lack of Guidance and Counselling materials is a major problem that hinders the implementation of Guidance and Counselling services. Alemu, (2013) support that, Guidance and Counselling provision in high schools needs the supporting materials for example, for pupils of low self-esteem needs motivational books to motivate them.

Further, the implementation of Guidance and Counselling services in the five secondary schools lacked parental participation. Mubanga, (2014) states that for Guidance and Counselling to be more successful in Zambia, it should involve teachers, parents and the community. However, this aspect of parental involvement is lacking in some communities. The study revealed that teachers had little or no time to provide Guidance and Counselling services to the pupils as most of the Guidance and Counselling teachers were subject teacher as well. Furthermore, another challenge was that of school Guidance and Counselling not being time-tabled in all the schools that took part in the study. Teachers had to find their own time outside teaching time table to provide Guidance and Counselling services to pupils. Therefore, that has created a big problem in the implementation of Guidance and Counseling services.

Equally, challenges faced included lack of trained teachers. In the schools were the study took place, most of the teachers who offered Guidance and Counselling were not trained in Guidance and Counselling but were just appointed by school administration to assist in providing Guidance and Counselling services. This means that most of the teachers were not appointed by the Teaching Service Commission to do such responsibilities. This was dangerous to the profession because these teachers were just using their own experience in providing these services. This aspect leaves one to wonder what sort of counselling pupils receive from teachers who have little or no knowledge about Guidance and Counselling.

Furthermore, other challenges were linked to lack of confidentiality by Guidance and Counselling teachers in schools. This lack of confidentiality by the Guidance and Counselling teachers could be to some extent, due to lack of training in Guidance and Counselling. These findings agree with Mahlangu (2011) who stated that for any Guidance and Counselling service to succeed there is much need for the counsellors to follow the code of ethics and keep high levels of confidentiality about client's information. It is therefore, very fundamental for the Guidance and Counselling providers to maintain confidentiality at all times because pupils feel safe and secured when their information is kept as confidential as possible by guidance teachers.

Equally, the lack of offices for Guidance and Counselling purposes was another challenge faced in the provision of Guidance and Counselling. This study showed that most schools only had shared offices in which they conducted counselling from. Guidance and Counselling teachers share offices with other teachers and in many cases these offices are overcrowded. This makes pupils to be uncomfortable thus feel shy to freely express their problems to the counsellor and end up not to seek help from these offices.

\section{CONCLUSION AND RECOMMENDATIONS}

The study established that, there are numerous Guidance and Counselling services implemented in selected secondary schools in Chilanga district of which the following a were educational, health or therapeutically, personal and vocational Guidance and Counselling services. In addition, the schools in Chilanga district were aware about the Guidance and Counselling services that are being provided to the pupils. It was revealed that some school counsellors did not keep confidentiality and pupils believed that their guidance teachers/counsellors had not been effective advocates in the area of guidance and counselling to benefit them. The study revealed that, there are many challenges faced in the implementation of Guidance and Counselling services and these included, lack of funds, lack of materials, lack of counselling offices, insufficient number of Guidance and Counselling teachers and the use of untrained teachers in the implementation of Guidance and Counselling services.

The Zambian Government through the Ministry of General Education needs:

i. Enhance Guidance and Counselling policy to guide the practice of Guidance and Counselling in schools.

ii. Create positions of full time school counsellors in secondary schools. 
Exploring the status of Guidance and Counselling services in Selected Public Secondary Schools in Chilanga District, Zambia

iii. Devise a deliberate training policy to ensure that all school counsellors receive training.

iv. Invest in the guidance reference materials, just the way it has invested in academic text books.

v. Ensure that guidance departments are monitored regularly by guidance standards officers so that some challenges are identified and addressed early.

vi. School counsellors should not be overload with too many non-counselling duties as it is the case presently.

\section{REFERENCES}

[1] Manchishi, P.C., Simui, F., Ndhlovu, D., \& Thompson, C.L. (2020). Tracing the Experiences of an Inaugural Postgraduate Distance Education Alumni cohort of the University of Zambia. Multidisciplinary Journal of Language and Social Sciences Education. 3 (1), 131-157. https://journals.unza.zm/index.php? journal $=$ mjlsse $\&$ page $=$ article $\& o p=v i e w \&$ path $\% 5 B \% 5 \mathrm{D}=180$

[2] Simui, F. (2018). Lived Experiences of Students with Visual Impairments at Sim University in Zambia: A Hermeneutic Phenomelogical Approach. Lusaka: University of Zambia. Unpublished PhD Thesis. http://dspace.unza.zm/handle/1234 56789/5884

[3] Simui, F., Kasonde-Ngandu, S., Cheyeka, A. \& Kakana, F. (2018). Unearthing dilemmas in thesis titles: Lived experience of a novice researcher in Sub-Saharan Africa. International Journal of Multidisciplinary Research and Development, 5(4), 99-105. http://www.allsubjectjournal. com/archives/2018/vol5/issue4/5-3-46

[4] UNESCO (2013). Strategy for All Global Monitoring: The challenges of Recruitment and Training Quality Teachers. Paris: UNESCO Institute of Statist.

[5] MOGE (2015). Guidelines on the Administration and Management of Guidance and counselling in Education System. Lusaka: MoGE.

[6] Bronfenbrenner, U. (1989). "Ecological Systems Theory". In Vasta, Ross (ed.). Annals of Child Development: Vol. 6. London, UK: Jessica Kingsley Publishers.

[7] Karega, M. (2008). School Conduct and indiscipline Issues. Daily Nation. Nairobi: NationMedia Ltd.

[8] Nkhata L. (2010). Guidance Services in Boarding Sigh Schools in Southern Province, Zambia, Unpublished M.A. Dissertation. University of Zambia, Lusaka.

[9] Makumba, C.E. (2013). The Status of Guidance and Counselling Provision in selected Basic Schools in Mumbwa District, Unpublished M.A. Dissertation. University of Zambia, Lusaka.

[10] Weissberg, T. M. \& Myrisks, C. H. (2007). Resolving Conflict Creativity in Community Psychology and the Schools: A Prosocial Behaviour and Academic Achievement. Chicago: Behavioural Research Associations.

[11] Mwamba, K. (2011). Guidance Service Provision in High Schools for Pupils with VisualImpairments: A Case of Sefula and Mumbwa high schools for the blind. 'Unpublished MA dissertation. University of Zambia.

[12] Ministry of Education (2009). Educational Statistical Bulletin. Directorate of Planning and Information. Lusaka: Zambia Educational Publishing House.

[13] Ministry of Education (2009). Zambia School Directory - Special Programs. Lusaka: Zambia Educational Publishing House

[14] Chipili, C.T., Ndhlovu, D., \& Simui, F. (2018). Access to Career Guidance through Information and Communication Technology by Learners with Visual Impairment in Selected Secondary Schools of Zambia. Zambia ICT Journal. 2 (1), 57-65. http://ictjournal.icict.org.zm/index.php/zictjournal /article/view/54

[15] Loescher, N. W. (2007). Introduction to Guidance and Counselling in Education: Crisis Counselling in Schools and Colleges. London: Oxford University Press.

[16] Macharia, M. (2007). Access to Success in School and Beyond. Nairobi: Sage Educational Media.

[17] Creswell, J. W. and Plano Clark, V. L. (2011). Designing and Conducting Mixed Methods Research (2nd ed.). Thousand Oaks, CA: Sage.

[18] Egbo, A.C. (2013). Development of Guidance and Counselling. Enugu: Joe Best Publishers.

[19] Kochhar, K. S. (2010). Education and Vocational Guidance in Secondary Schools. New Delhi: Sterling Publishers, Private Ltd.

[20] Eyo, M.B, Joshua, A.M \& Esuong, A.E. (2010). Attitude of Secondary School students towards Guidance and Counselling services in Cross River State. Edo Journal of Counselling 3(1):87-99.

[21] Alemu, Y. (2013). Assessment of the Provisions of Guidance and Counselling Services in Secondary Schools of East Harare Zone and Hareri Region, Ethiopia. Middle Eastern\& African Journal of Educational Research 2:28-37. 
Exploring the status of Guidance and Counselling services in Selected Public Secondary Schools in Chilanga District, Zambia

[22] Mubanga, D.S (2014). Investigating the Role of School Guidance and Counselling in Education for Sustainable Development. Med Dissertation. Lusaka: The University of Zambia

[23] Mahlangu, V. (2011). Dilemma in School District in Managing Career Counselling in South Africa Journal of Emerging. Trends in Educational Research and Policy Studies 2:239-245.

\section{AUTHORS' BIOGRAPHY}

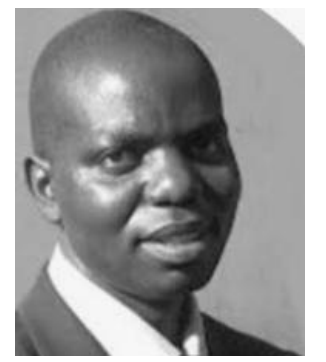

Francis Simui, PhD, Simui Francis is a Canon Collins Trust/Chevening Alumni at the University of Manchester. He holds a $\mathrm{PhD}$ in Inclusive Education. $\mathrm{He}$ is a member of EENET's Steering Group of professionals and academicians in Inclusive Education with representatives worldwide. His areas of specialization include: (i) developing and managing an effective Open and Distance Education system; (ii) developing and managing an effective inclusive education system; and (iii) designing monitoring and evaluation systems. Currently, he works for the University of Zambia under the Institute of Distance Education (IDE) as Head of Department, Programmes Development \& Production as well as Lecturer of Inclusive \& Special Education.

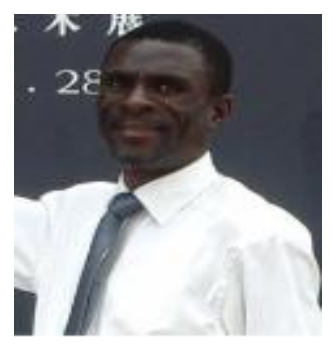

Kasonde Mundende(Mr.) is a Lecturer of Geography at the University of Zambia, Lusaka, Zambia. He serves at the Institute of Distance Education (IDE) of the University of Zambia (UNZA) currently as the Head of Department of Learner Support Services. His passion is in Geography Education, Distance Education/Learning and Instructional design and technology. He has the following qualifications: Primary Teachers"e Certificate, Secondary Teacher Diploma (Single Major Mathematics), Bachelor of Arts with Education (B.A. Ed) (Single Major Geography) and Master of Education (M. Ed) -Geography Education. Additionally, he possesses a Certificate for Distance Education Practitioners (CDEP) from Botswana College of Distance and Open Learning (BOCODOL).Currently, he is pursuing Master of Instructional Design and Technology with Malaysia Open University and Philosophy of Doctorate $(\mathrm{PhD})$ in Geography Education.

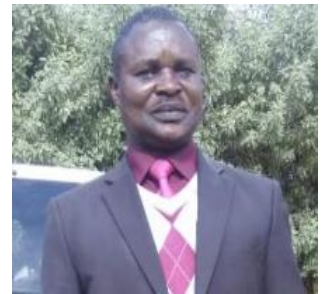

Christopher Kabamba An educationist with 26 years of teaching experience in Zambia. He has served in various positions such as class teacher, Head of department and Deputy Head teacher. An experienced teacher of English Language and Geography. In the area of research, he is interested in Pupil Academic Performance as well as Counselling support services to school personnel.

Citation: Christopher Kabamba, et.al. "Exploring the status of Guidance and Counselling services in Selected Public Secondary Schools in Chilanga District, Zambia" International Journal of Humanities Social Sciences and Education (IJHSSE), vol 7, no. 6, 2020, pp. 57-66. doi: http://dx.doi.org/10.20431/2349-0381.0706007.

Copyright: (C) 2020 Authors. This is an open-access article distributed under the terms of the Creative Commons Attribution License, which permits unrestricted use, distribution, and reproduction in any medium, provided the original author and source are credited. 